\title{
ANTIMICROBIAL ACTIVITIES OF INDOLOCARBAZOLE AND BIS-INDOLE PROTEIN KINASE C INHIBITORS
}

\author{
Martine Sancelme, Serge Fabre and Michelle Prudhomme* \\ Université Blaise Pascal, Laboratoire de Chimie Organique Biologique, \\ URA 485, 63177 Aubière Cedex, France
}

(Received for publication February 14, 1994)

\begin{abstract}
The antimicrobial activities of twenty-two substances structurally related to staurosporine, aglycone in the indolocarbazole and bis-indole series were examined against Streptomyces chartreusis and Streptomyces griseus, Bacillus cereus, Escherichia coli, Candida albicans and Botrytis cinerea. Inhibition of sporulation was examined also on the two species of Streptomyces. Unlike literature reports for efficient protein kinase inhibitors, staurosporine and $\mathrm{K}-252 \mathrm{a}$, no evident correlation could be found either between protein kinase inhibitory potencies and inhibition of sporulation of the Streptomyces species, or protein kinase inhibitory potencies and growth of all microorganisms tested. A weak activity against $C$. albicans was observed for the chloro-indolocarbazole compounds as already reported for structurally related substances from the cyanobacterium Tolypothrix tjipanasensis.
\end{abstract}

Streptomycetes are Gram-positive bacteria which form a spore-producing aerial mycelium. It was found recently that the microbial indolocarbazole metabolites, staurosporine ${ }^{1)}$ and K-252a ${ }^{2)}$ (Fig. 1), inhibit aerial mycelium formation and antibiotic production by Streptomyces griseus ${ }^{3}$. These compounds are known also as inhibitors of eukaryotic protein kinase $\mathrm{C}$.

To determine if there was a general link between activity on protein kinase $\mathrm{C}$ and inhibition of spore formation, the in vitro growth inhibitory effect of twenty-two compounds in the indolocarbazole and bis-indole series were tested against $S$. griseus and Streptomyces chartreusis. The activities of these twenty-two compounds towards protein kinase $\mathrm{C}$ and protein kinase $\mathrm{A}$ have been determined previously; some of them were active, others not ${ }^{4 \sim 7}$. Production of the secondary metabolite calcimycin (A 23187) by $S$. chartreusis was examined when the culture was incubated with an efficient protein kinase $\mathrm{C}$ inhibitor and with a compound inactive towards this enzyme. The antimicrobial activities against Bacillus cereus, Escherichia coli, Candida albicans and Botrytis cinerea were determined also.

Fig. 1.

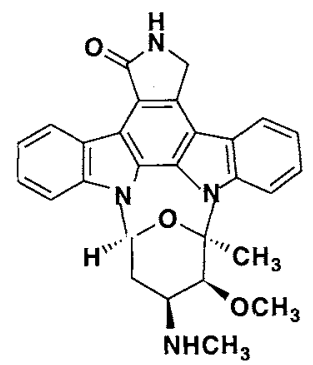

Staurosporine $\mathrm{IC}_{50} \mathrm{PKC}=3 \mathrm{nM}$

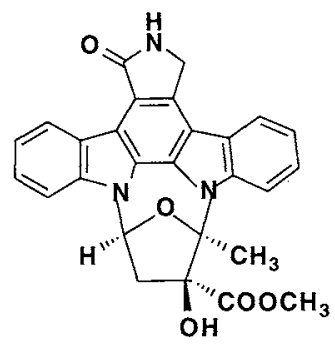

$\mathrm{K}-252 \mathrm{a} \mathrm{IC}_{50} \mathrm{PKC}=32.9 \mathrm{nM}$ 


\section{Results and Discussion}

Rebeccamycin 1 (laboratory stock sample) was isolated from cultures of Saccharotrix aerocolonigenes ${ }^{8)}$. Compounds 2 22 were prepared by either total synthesis or hemisynthesis from rebeccamycin.

Compounds $2 \sim 11$, structurally related to staurosporine or K-252a aglycones, have different framework flexibilities and different functions (imide, amide and amide-alcohol) on the non-indolic heterocycle (Fig. 2) ${ }^{4}$.

Compounds 12 16 (Fig. 3) are amides in the indolocarbazole and bis-indole series in which the amide group is acyclic; these compounds, structurally related to those shown in Fig. 2, have no inhibitory effect on protein kinase $\mathrm{C}$ and protein kinase $\mathrm{A}$, as the rigid cyclic structure of the amide group is compulsory for activity against these enzymes ${ }^{5}$.

Compounds 17 21 (Fig. 4) were obtained by hemisynthesis from rebeccamycin ${ }^{6}$.

Fig. 2.

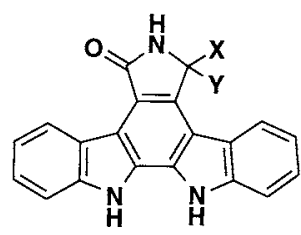

$2 \quad \mathrm{X}=\mathrm{Y}=\mathrm{O}$

$3 \mathrm{X}=\mathrm{H} ; \mathrm{Y}=\mathrm{OH}$

$4 \mathrm{X}=\mathrm{Y}=\mathrm{H}$<smiles>[X]C1([X])NC(=O)C(c2c[nH]c3ccccc23)=C1c1c[nH]c2ccccc12</smiles>

$5 \mathrm{X}=\mathrm{Y}=\mathrm{O}$

$6 \mathrm{X}=\mathrm{H} ; \mathrm{Y}=\mathrm{OH}$

$7 \mathrm{X}=\mathrm{Y}=\mathrm{H}$<smiles>[R]C1([X])NC(=O)[C@@H](c2c[nH]c3ccccc23)[C@H]1c1c[nH]c2ccccc12</smiles>

$8 \mathrm{X}=\mathrm{Y}=\mathrm{O} ; \mathrm{R}=\mathrm{H}$

$9 \mathrm{X}=\mathrm{H} ; \mathrm{Y}=\mathrm{OH} ; \mathrm{R}=\mathrm{H}$

$10 \mathrm{X}=\mathrm{Y}=\mathrm{H} ; \mathrm{R}=\mathrm{H}$

$11 \mathrm{X}=\mathrm{Y}=\mathrm{O} ; \mathrm{R}=\mathrm{CH}_{2} \mathrm{OH}$

Fig. 3.<smiles></smiles>

$12 \mathrm{R}_{1}=\mathrm{H} ; \mathrm{R}_{2}=\mathrm{H}$

$13 \mathrm{R}_{1}=\mathrm{CH}_{3} ; \mathrm{R}_{2}=\mathbf{H}$

$14 \mathrm{R}_{1}=\mathrm{CH}_{3} ; \mathrm{R}_{2}=\mathrm{CH}_{3}$<smiles></smiles>

$15 \mathrm{R}_{1}=\mathrm{CH}_{3} ; \mathrm{R}_{2}=\mathrm{H}$

16 $\mathrm{R}_{1}=\mathrm{CH}_{3} ; \mathrm{R}_{2}=\mathrm{CH}_{3}$

Fig. 4.

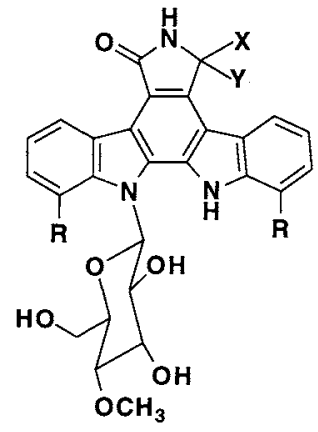<smiles>[X]C1([X])NC(=O)c2c1c1c3cccc(Cl)c3[nH]c1c1[nH]c3c(Cl)cccc3c21</smiles>

Rebeccamycin $1 \mathrm{X}=\mathrm{Y}=\mathrm{O} ; \mathrm{R}=\mathrm{Cl}$

$17 \mathrm{X}=\mathrm{Y}=\mathrm{O} ; \mathrm{R}=\mathrm{H}$

$18 \mathrm{X}=\mathrm{Y}=\mathrm{H} ; \mathrm{R}=\mathrm{H}^{7)}$

$20 \quad \mathrm{X}=\mathrm{Y}=\mathrm{O}$

$21 \mathrm{X}=\mathrm{Y}=\mathrm{H}$

$19 \mathrm{X}=\mathrm{Y}=\mathrm{H} ; \mathrm{R}=\mathrm{Cl}$ 
Compound 22 (Fig. 5), a biomimetic analog of K252a was prepared by coupling 2 with methyl-2,5dimethoxy-tetrahydrofuran-3-carboxylate using $p$-toluenesulfonic acid ( $p$-TsOH) in refluxing $\mathrm{CH}_{2} \mathrm{Cl}_{2}$.

Methyl-2,5-dimethoxy-tetrahydrofuran-3-carboxylate was prepared from commercial 2,5-dimethoxytetrahydrofuran-3-carbaldehyde by oxidation with potassium permanganate in a tert-butylalcohol - aqueous $\mathrm{NaH}_{2} \mathrm{PO}_{4}$ system according to the method described by ABIKo et al. ${ }^{9}$, on carbaldehyde-tetrahydropyran moieties.

Since both staurosporine and K-252a allow growth of $S$. griseus even at high concentrations but inhibit its aerial mycelium formation, we examined the inhibition of both growth and sporulation of the two species of Streptomyces tested and the inhibition of growth of the other microorganisms tested. The Fig. 5. results are summarised in Table 1.

No correlation was observed between activity against protein kinase $\mathrm{C}(\mathrm{PKC})$ and antimicrobial activity on $B$. cereus. Of the few compounds inactive towards $B$. cereus $2,15,17,20$ and 22,2 and 22 are efficient PKC inhibitors while 15, 17 and 20 are not.

Few of the products tested exhibited antifungal

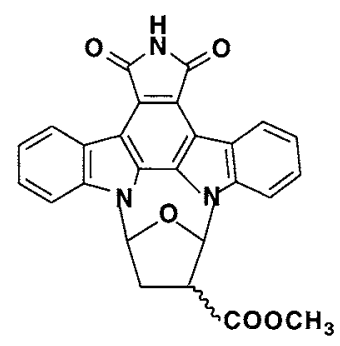

Table 1. Inhibitory potencies of compounds $1 \sim 22$ against protein kinase $\mathrm{C}(\mathrm{PKC})$ and protein kinase $\mathrm{A}$ (PKA).

\begin{tabular}{|c|c|c|c|c|c|c|c|c|c|c|}
\hline \multirow{2}{*}{$\begin{array}{l}\text { Pro- } \\
\text { duct }\end{array}$} & \multirow{2}{*}{$\begin{array}{l}\mathrm{IC}_{50} \\
\mathrm{PKC} \\
(\mu \mathrm{M})\end{array}$} & \multirow{2}{*}{$\begin{array}{c}\mathrm{IC}_{50} \\
\text { PKA } \\
(\mu \mathrm{M})\end{array}$} & \multicolumn{2}{|c|}{$\begin{array}{l}\text { S. chartreusis } \\
\text { NRRL } 11407\end{array}$} & \multicolumn{2}{|c|}{$\begin{array}{c}\text { S. griseus } \\
\text { ATCC } 23345\end{array}$} & \multirow{2}{*}{$\begin{array}{c}\text { E. coli } \\
\text { ATCC } 11303\end{array}$} & \multirow{2}{*}{$\begin{array}{c}\text { B. cereus } \\
\text { ATCC } 14879\end{array}$} & \multirow{2}{*}{$\begin{array}{l}\text { C. albicans } \\
\text { IP } 444\end{array}$} & \multirow{2}{*}{$\begin{array}{l}\text { B. cinered } \\
\text { DSM } 877\end{array}$} \\
\hline & & & g. & sp. & g. & sp. & & & & \\
\hline $\mathbf{1}^{\mathrm{a}}$ & $>100$ & $>100$ & + & - & + & - & - & + & - & - \\
\hline 2 & 44.7 & 60 & - & - & - & - & - & - & - & - \\
\hline 3 & 22.1 & 34 & ++ & ++ & ++ & + & - & $+t$ & \pm & \pm \\
\hline 4 & 2.45 & 25.7 & - & - & - & - & - & + & - & - \\
\hline 5 & 0.087 & 2.7 & +++ & +++ & +++ & $+t+$ & - & ++ & - & - \\
\hline 6 & 7.6 & $>50$ & \pm & - & + & - & - & + & - & - \\
\hline 7 & 2.5 & 32 & $+t$ & + & + & + & - & + & - & - \\
\hline 8 & $>100$ & $>100$ & ++ & +++ & ++ & $+t+$ & - & + & - & \pm \\
\hline 9 & $>100$ & $>100$ & + & - & \pm & - & - & + & - & - \\
\hline 10 & $>50$ & $>50$ & + & ++ & $\overline{+}$ & - & - & + & - & - \\
\hline 11 & 16 & $>100$ & +++ & +++ & ++ & ++ & - & + & - & - \\
\hline 12 & $>100$ & $>100$ & ++ & +++ & ++ & ++ & - & ++ & - & - \\
\hline 13 & $>100$ & $>150$ & + & \pm & + & \pm & - & + & - & - \\
\hline 14 & $>100$ & $>100$ & + & ++ & + & + & - & \pm & - & - \\
\hline 15 & $>100$ & $>100$ & $+t$ & - & + & - & - & - & - & - \\
\hline 16 & $>100$ & $>100$ & + & - & + & - & - & + & - & - \\
\hline 17 & $>100$ & $>150$ & \pm & - & - & - & - & - & - & - \\
\hline 18 & 3.7 & n.d. & + & - & - & - & - & ++ & - & - \\
\hline 19 & 28.8 & $>150$ & ++ & \pm & ++ & + & - & + & - & - \\
\hline 20 & $>50$ & $>100$ & - & - & - & - & - & - & + & - \\
\hline 21 & $>100$ & $>100$ & $+t$ & $+t$ & $+t$ & + &.- & +++ & + & \pm \\
\hline 22 & 4.85 & 34.7 & - & - & - & - & - & - & - & - \\
\hline
\end{tabular}

$\left(\mathrm{IC}_{50} \mu \mathrm{M}\right)$; in vitro growth inhibitory effect against different microorganisms (for the 2 species of Streptomyces: g. means inhibition of growth, sp. means inhibition of sporulation). $(+++),(++),(+),( \pm)$ and $(-)$ mean strong, medium, weak, very weak and no activity. The size of zones of growth inhibition was $>12 \mathrm{~mm}(+++)$, $10 \sim 12 \mathrm{~mm}(++), 7 \sim 9 \mathrm{~mm}(+), 6 \sim 7 \mathrm{~mm}( \pm)$.

a Antimicrobial activities are in agreement with literature. ${ }^{9)}$ 
Fig. 6. Effects of compounds 5 and $\mathbf{1 2}$ on growth and sporulation of $S$. chartreusis.

a) Photograph of Petri plates; b), c), d) scanning electron microscopy photographs. b) S. chartreusis as control, bar represents $5.0 \mu \mathrm{m}$. c) Inhibition of sporulation by 5 , bar represents $5.0 \mu \mathrm{m}$. d) Inhibition of sporulation by 12 , bar represents $5.0 \mu \mathrm{m}$.
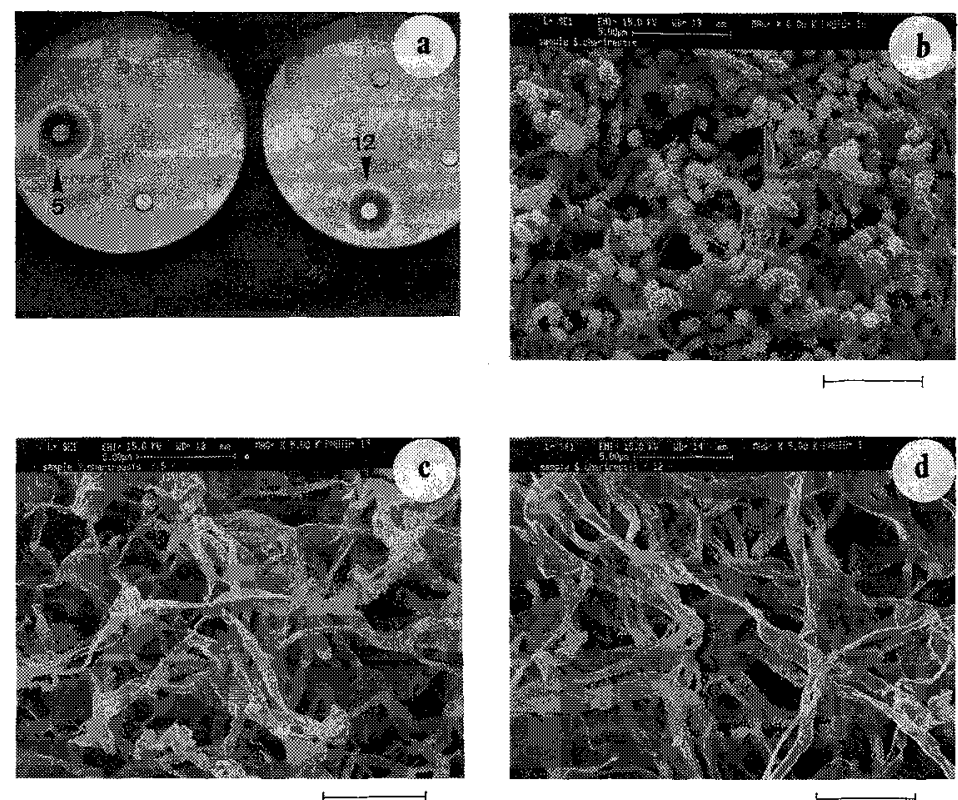

Fig. 7. Effects of compound 5 on sporulation of S. griseus.

Scanning electron microscopy photographs. a) $S$. griseus as control, bar represents $5.0 \mu \mathrm{m}$. b) Inhibition of sporulation by 5 , bar represents $5.0 \mu \mathrm{m}$.
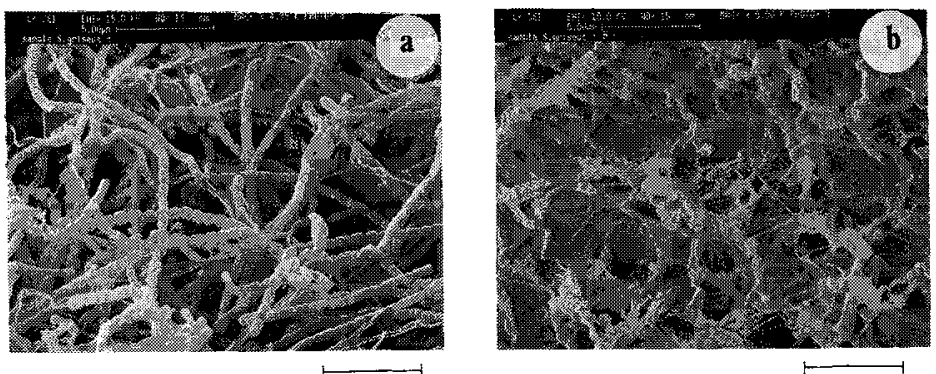

activities; 20 and 21, which were active against $C$. albicans are chloro-indolocarbazole systems, and their fungicidal activity was comparable to that observed with chloro-indolocarbazole tjipanazoles isolated from Tolypothrix tjipanasensis ${ }^{10}$ ). Examples of the effects of compounds 5 (active against PKC) and 12 (inactive against PKC) on growth and sporulation of $S$. chartreusis are shown in Fig. 6. Fig. 7 shows the activity of 5 on $S$. griseus.

In vitro phosphorylation reactions revealed multiple phosphorylated proteins in S. griseus ${ }^{3)}$. Staurosporine and $\mathrm{K}-252 \mathrm{a}$ which are eukaryotic protein kinase inhibitors (staurosporine: $\mathrm{IC}_{50} \mathrm{PKC} 3 \mathrm{nM}$ and ranging from 3 to $30 \mathrm{nM}$ on other protein kinases ${ }^{11)}, \mathrm{K}-252 \mathrm{a} \mathrm{IC}_{50} \mathrm{PKC} 32.9 \mathrm{nM}^{2)}$ ) also inhibit the phosphorylation of several cellular proteins in $S$. griseus. These microbial metabolites inhibit aerial mycelium 
formation and pigment production by $S$. griseus. This suggests a relationship between protein phosphorylation and both aerial mycelium formation and pigment formation. Among the compounds implicated in aerial mycelium formation of different Streptomyces are A-factor and the small protein SapB. A-factor or related compounds are secreted by many species of Streptomyces and thought to diffuse freely into cells, bind a cytoplasmic protein and inactivate the protein's ability to repress sporulation ${ }^{12)}$. SapB protein production, triggered by extracellular signals, plays an important role in the formation of aerial hyphae ${ }^{13)}$. It appears that staurosporine and K-252a inhibit the formation of the compounds involved in sporulation or interact with them leading to their inactivation, and so it was concluded that these mechanisms are implicated in the inhibition of protein phosphorylation induced by the protein kinase $\mathrm{C}$ inhibitors, staurosporin or K-252a. In this light, the results we obtained on the two strains of Streptomyces were quite unexpected:

1. Unlike staurosporine and K-252a, the active PKC inhibitors 3, 5, 7, 11, 18, 19, which inhibit the sporulation, also inhibited the growth of the Streptomyces species tested.

2. Efficient PKC inhibitors 2, 4, and $\mathbf{2 2}$ had no activity on the Streptomyces species tested.

3. 8 and $\mathbf{1 2}$ are inactive against PKC, but very strongly inhibited growth close to the disk and sporulation at slightly lower concentrations.

4. 1,9 and 16, inactive against PKC, inhibited only growth.

5. Only compound $\mathbf{2 0}$ was both inactive on PKC and on the Streptomyces species.

Since staurosporine, K-252a and the active compounds tested interact with the ATP binding site of the catalytic domain common to all protein kinases, they exhibit no marked specificity towards these enzymes, and so protein kinase $\mathrm{C}$, assuming it is implicated in the inhibition of sporulation, it's probably not the sole enzyme system involved.

Importantly, staurosporine and $\mathrm{K}-252 \mathrm{a}$ are more active protein kinase inhibitors $\left(\mathrm{IC}_{50}\right.$ in the $\mathrm{nM}$ range) than any of our compounds, and yet do not inhibit growth at the same concentration, in contrast to 5 , the strongest protein kinase $\mathrm{C}$ inhibitor tested here. Since 8 and 12, which are inactive against PKC, inhibit the sporulation of $S$. chartreusis and $S$. griseus, the mechanism involved in the inhibition of sporulation does not seem directly correlated with the inhibition of protein phosphorylation by PKC.

The results obtained with $\mathbf{2 , 4}$ and 22, which are active compounds against PKC but inactive on the microorganisms tested, are surprising. The lack of activity on Streptomyces could be due to absence of penetration into the cells or absence of diffusion through the gelose or metabolism by the cells. To investigate this, cultures of $S$. chartreusis were incubated with compounds $\mathbf{4}$ and $\mathbf{5}$ which are both active against PKC; 5 inhibited sporulation while 4 did not. After four days of incubation, the cultures were extracted as indicated in the experimental section; 5 was recovered unchanged while metabolism of 4 was observed from TLC and ${ }^{1} \mathrm{H}$ NMR spectrum. Metabolism of 4 by the microorganism may therefore explain its inactivity.

As described in the literature ${ }^{3)}$, inhibition of sporulation seems to parallel that of secondary metabolite formation. Accordingly, we examined the production of the ionophorous antibiotic A23187 by $S$. chartreusis after incubation of cultures with compounds $\mathbf{4}$ and 5 comparatively to a blank. In the blank, the production of A23187 began after two days, peaking after four days. When cultures were incubated with 5, A23187 production was arrested until the fourth day and then began slowly. Incubation with 4 led to both reduced growth and A23187 production, and biotransformation of the PKC inhibitor.

It would be relevant to examine if the amides 12, 13, 14, which are inactive against $\mathrm{PKC}$ but inhibit 
the sporulation of $S$. chartreusis, are metabolised into efficient PKC inhibitors. This would explain their effect on sporulation. If not, it may be that the inhibition of sporulation does not necessarily imply the inhibition of protein phosphorylation by PKC. We are currently investigating this possibility. These results also show that the inhibition of sporulation of Streptomyces species cannot be used as a rapid and cheap early test for the inhibition of PKC.

\section{Experimental}

IR spectra were recorded on a Perkin-Elmer 881 spectrometer $\left(v\right.$ in $\left.\mathrm{cm}^{-1}\right)$, NMR spectra on a Bruker MSL $300\left({ }^{1} \mathrm{H}: 300 \mathrm{MHz},{ }^{13} \mathrm{C}: 75.45 \mathrm{MHz}\right.$ ) (chemical shifts $\delta$ in ppm, the following abbreviations are used: singlet (s), doublet (d), triplet (t), quadruplet (q), multiplet (m), tertiary carbons (C tert), quaternary carbons (C quat)). Mass spectra (EI) were determined at the Service Central d'Analyses, CNRS (Vernaison) on a VG.ZAB SEQ and at CESAMO (Talence) on a high resolution FISONS Autospec-Q spectrometer. Chromatographic purifications were performed with flash Geduran SI 60 (Merck) $0.040 \sim 0.063 \mathrm{~mm}$.

\section{2,5-Dimethoxy-tetrahydrofuran-3-carboxylic Acid}

Commercial 2,5-dimethoxy-tetrahydrofuran-3-carbaldehyde ( $1 \mathrm{~g} ; 6.25 \mathrm{mmol})$ in tert-BuOH (37 ml) was diluted in a $5 \% \mathrm{NaH}_{2} \mathrm{PO}_{4}$ buffer $(\mathrm{pH} 4.4 ; 25 \mathrm{ml})$. A 1 M $\mathrm{KMnO}_{4}$ solution $(37.5 \mathrm{ml} ; 37.5 \mathrm{mmol})$ was added. The mixture was stirred for 10 minutes at room temperature, neutralised with saturated aqueous $\mathrm{Na}_{2} \mathrm{SO}_{3}$ then acidified to $\mathrm{pH} 3.5$ with diluted $\mathrm{HCl}$. After extraction with AcOEt, purification by flash chromatography (AcOEt - cyclohexane 50:50) afforded the acid as colourless crystals $\left(542 \mathrm{mg} ; 3.08 \mathrm{mmol} ; 49 \%\right.$ yield). ${ }^{1} \mathrm{H}$ NMR $\left(60 \mathrm{MHz}, \mathrm{CDCl}_{3}\right): 2.3\left(2 \mathrm{H}, \mathrm{m}, \mathrm{C}_{4}-\mathrm{H}_{2}\right) ; 3.1\left(1 \mathrm{H}, \mathrm{m}, \mathrm{C}_{3}-\mathrm{H}\right) ; 3.4\left(6 \mathrm{H}, \mathrm{s}, \mathrm{OCH}_{3}\right) ; 5.2\left(2 \mathrm{H}, \mathrm{m}, \mathrm{C}_{2}-\mathrm{H}\right.$, $\left.\mathrm{C}_{5}-\mathrm{H}\right) ; 10.2(1 \mathrm{H}$, brs, $\mathrm{COOH})$.

\section{Methyl-2,5-dimethoxy-tetrahydrofuran-3-carboxylate}

To the above acid $(2.66 \mathrm{~g} ; 15.1 \mathrm{mmol})$ in methanol $(10 \mathrm{ml})$ was added $\mathrm{CH}_{2} \mathrm{~N}_{2}$ in ether until a yellow colour, indicating an excess of diazomethane persisted. After evaporation of the solvents, purification by flash chromatography (AcOEt - cyclohexane 50:50) afforded the ester as a colorless oil $(2.810 \mathrm{~g} ; 14.8 \mathrm{mmol}$; $98 \%$ yield). IR ( $\mathrm{KBr}) v_{\mathrm{C}=\mathrm{o}} 1740$; Mass (EI) $\left(\mathrm{M}-\mathrm{OCH}_{3}\right)^{+} 159(30 \%) .{ }^{1} \mathrm{H}$ NMR $\left(60 \mathrm{MHz}, \mathrm{CDCl}_{3}\right): 2.3$ $\left(2 \mathrm{H}, \mathrm{m}, \mathrm{C}_{4}-\mathrm{H}_{2}\right) ; 3.1\left(1 \mathrm{H}, \mathrm{m}, \mathrm{C}_{3}-\mathrm{H}\right) ; 3.4\left(6 \mathrm{H}, \mathrm{s}, \mathrm{OCH}_{3}\right) ; 3.9\left(3 \mathrm{H}, \mathrm{s}, \mathrm{COOCH}_{3}\right): 5.3\left(2 \mathrm{H}, \mathrm{m}, \mathrm{C}_{2}-\mathrm{H}, \mathrm{C}_{5}-\mathrm{H}\right)$. ${ }^{13} \mathrm{C} \mathrm{NMR}\left(15 \mathrm{MHz}, \mathrm{CDCl}_{3}\right): 32.3 ; 33.7 ; 35.1\left(\mathrm{C}_{4}\right) ; 47.3 ; 48.8 ; 49.7 ; 51.9 ; 52.3 ; 55.0 ; 55.3 ; 55.5\left(\mathrm{COOCH}_{3}\right.$, $\left.\mathrm{OCH}_{3}, \mathrm{C}_{3}\right) ; 104.1 ; 105.0 ; 105.2 ; 106.2 ; 107.7\left(\mathrm{C}_{2}, \mathrm{C}_{5}\right) ; 169.5 ; 170.0 ; 171.9 ; 172.7\left(\mathrm{COOCH}_{3}\right)$.

10-Methyloxycarbonyl-9,10,11,12-tetrahydro-9,12-epoxy-(1H)-diindolo[1,2,3,f-g: $3^{\prime}, 2^{\prime}, 1^{\prime}$-k-j]-pyrrolo$[3,4-i][1,6]$-benzodiazocin-1,3-(2H)-dione (22)

To compound $2(258 \mathrm{mg} ; 0.794 \mathrm{mmol})$ in $\mathrm{CH}_{2} \mathrm{Cl}_{2}(90 \mathrm{ml})$ were added the above ester $(323 \mathrm{mg} ; 1.7 \mathrm{mmol}$; 2.1 equiv) and catalytic amounts of $p$-TsOH. The mixture was refluxed for 20 hours then poured into water and extracted with AcOEt. Purification by flash chromatography (AcOEt-cyclohexane 20:80) afforded 22 as a yellow fluorescent solid $\left(23 \mathrm{mg} ; 0.051 \mathrm{mmol} ; 6 \%\right.$ yield). IR (KBr) $v_{\mathrm{N}-\mathrm{H}} 3200 v_{\mathrm{C}=\mathrm{O}} 1750 ; \mathrm{mp}$ $253 \sim 257^{\circ} \mathrm{C}$. Exact mass calculated for $\mathrm{C}_{26} \mathrm{H}_{17} \mathrm{~N}_{3} \mathrm{O}_{5}: 451.1168$ found $451.1146 .{ }^{1} \mathrm{H}$ NMR (300 MHz, DMSO-d $\left.d_{6}\right): 2.0 \sim 2.2\left(2 \mathrm{H}, \mathrm{m}, \mathrm{C}_{11}-\mathrm{H}_{2}\right) ; 2.9 \sim 3.2\left(1 \mathrm{H}, \mathrm{m}, \mathrm{C}_{10}-\mathrm{H}\right) ; 3.40$ and $3.45\left(3 \mathrm{H}, 2 \mathrm{~s}, \mathrm{COOCH}_{3}\right) ; 6.30$ $(1 \mathrm{H}, \mathrm{t}, J=8 \mathrm{~Hz}) ; 7.12(1 \mathrm{H}, \mathrm{s}) ; 7.38(2 \mathrm{H}, \mathrm{m}) ; 7.54(2 \mathrm{H}, \mathrm{t}, J=9 \mathrm{~Hz}) ; 7.71(1 \mathrm{H}, \mathrm{d}, J=9 \mathrm{~Hz}) ; 7.94(1 \mathrm{H}, \mathrm{d}$, $J=9 \mathrm{~Hz}) ; 9.11(1 \mathrm{H}, \mathrm{d}, J=9 \mathrm{~Hz}) ; 9.16(1 \mathrm{H}, \mathrm{d}, J=9 \mathrm{~Hz}) ; 11.02$ and $11.10(1 \mathrm{H}, 2 \mathrm{~s}, \mathrm{NH}) .{ }^{13} \mathrm{CNMR}(75.47 \mathrm{MHz}$, DMSO-d $\left.)_{6}\right): 30.1\left(\mathrm{C}_{11}\right) ; 50.9\left(\mathrm{COOCH}_{3}\right) ; 56.0 ; 61.3 ; 65.4\left(\mathrm{C}_{9}, \mathrm{C}_{10}, \mathrm{C}_{12}\right) ; 109.9 ; 112.4 ; 120.3 ; 120.8 ; 124.4$; $124.8 ; 126.9$ (2C) (C tert); $116.0 ; 117.5 ; 119.2 ; 121.2 ; 128.0 ; 128.9 ; 140.2 ; 141.3$ (C quat); $167.5 ; 170.3 ; 170.9$ $(\mathrm{C}=\mathrm{O})$.

\section{Antimicrobial Tests}

Six strains were tested: 3 Gram-positive bacteria (B. cereus ATCC 14879, S. chartreusis NRRL 11407, S. griseus ATCC 23345), a Gram-negative bacterium (E. coli ATCC 11303) a yeast (C. albicans 444 from Pasteur Institute) and a filamentous fungus (B. cinerea DSM 877). Antibacterial activity was determined 
by the conventional paper disk (Durieux, No. $268,6 \mathrm{~mm}$ in diameter) diffusion method using the following nutrient media: Mueller-Hinton (Difco) for B. cereus and E. coli, Sabouraud agar (Difco) for C. albicans and $B$. cinerea and Emerson agar $(0.4 \%$ beef extract, $0.1 \%$ yeast extract, $0.4 \%$ peptone, $1 \%$ dextrose, $0.25 \% \mathrm{NaCl}, 2 \%$ agar, $\mathrm{pH} 7.0$ (Difco)) for the Streptomyces. Growth inhibition was examined after 24 hours incubation at $27^{\circ} \mathrm{C}\left(37^{\circ} \mathrm{C}\right.$ for $E$. coli $)$. Inhibition of sporulation was examined 3 to 5 days later. Products 1 22 were dissolved in DMSO and a paper disk containing each of the products $(300 \mu \mathrm{g})$ was placed on regeneration medium seeded with spores.

For the control of calcimycin (A 23187) production by S. chartreusis in the presence of protein kinase $C$ inhibitor, the inhibitor $\left(600 \mu \mathrm{g}\right.$ in $10 \mathrm{ml}$ of DMSO) was introduced into the culture medium $(100 \mathrm{ml})^{14)}$. After 1, 2, 3, 4 days of incubation, the medium was filtered off, the mycelium was extracted with ethanol and the filtrate with ethyl acetate, after concentration, the A23187 production was examined by TLC and compared with a blank.

\section{Scanning Electron Microscopy}

Pieces of mycelium were cut out and fixed under osmium tetroxide vapour for 15 hours, then allowed to dry for 12 hours. After sputter coating with gold for 2 minutes under vacuum, the mycelium was examined under a Cambridge stereoscan 360 scanning electron microscope.

\section{References}

1) TAMAOKI, T.; H. NOMOto, I. TAKAhash, Y. Kato, M. MoRimoto \& F. TOMITA: Staurosporine, a potent inhibitor of phospholipid $/ \mathrm{Ca}^{2+}$ dependent protein kinase. Biochem. Biophys. Res. Commun. 135: 397 402, 1986

2) KaSE, H.; K. IWAHASH \& Y. Matsuda: K-252a, a potent inhibitor of protein kinase C from microbial origin. J. Antibiotics 39; 1059 1065, 1986

3) Hong, S. K.; A. Matsumoto, S. Horinouchi \& T. Beppu: Effects of protein kinase inhibitors on in vitro protein phosphorylation and cellular differenciation of Streptomyces griseus. Mol. Gen. Genet. 236: 347 354, 1993

4) Farre, S.; M. Prudhomme \& M. Rapp: Protein kinase C inhibitors; Structure-activity relationships in K-252c related compounds. Bioorganic \& Medicinal Chemistry 1: 193 196, 1993

5) Fabre, S.; M. Prudhomme \& M. RapP: Studies on protein kinase $C$ inhibitors; Structure-activity relationships in indolocarbazole and bis-indole series. Bioorganic \& Medicinal Chemistry 1: 189 192, 1993

6) FARRE, S.; M. PRUDHOMme \& M. RAPP: Preparation of synthons for the synthesis of protein kinase C inhibitors from rebeccamycin. BioMed. Chem. Lett. 2: 449 452, 1992

7) FABRE, S.; M. PRUDHOMME \& M. RAPP: Indolocarbazole protein kinase Cinhibitors from rebeccamycin. Bioorganic \& Medicinal Chemistry 2: 73 77, 1994

8) Bush, J. A.; B. H. Long, J. J. Catino, W. T. Bradner \& K. Tomita: Production and biological activity of rebeccamycin, a novel antitumor agent. J. Antibiotics 40: 668 678, 1987

9) AвiKo, A.; J. C. RoberTs, T. TAKemasa \& S. Masamune: $\mathrm{KMnO}_{4}$ revisited: oxidation of aldehydes to carboxylic acids in the tert-butylalcohol-aqueous $\mathrm{NaH}_{2} \mathrm{PO}_{4}$ system. Tetrahedron Lett. 27: 4537 4540, 1986

10) Bonjouklian, R.; T. A. Smitka, L. E. Doolin, R. M. Molloy, M. Debono, S. A. Shaffer, R. E. Moore, J. B. StEWART \& G. M. L. PatTerson: Tjipanazoles, new antifungal agents from the blue-green alga Tolypothrix tjipanasensis. Tetrahedron 47: 7739 7750, 1991

11) Herbert, J. M.; E. Seban \& J. P. Maffrand: Characterization of specific binding sites for $\left[{ }^{3} \mathrm{H}\right]$-staurosporine on various kinases. Biochem. Biophys. Res. Commun. 171: 189 195, 1990

12) Chater, K. F.: Genetics of differenciation in Streptomyces. Annu. Rev. Microbiol. 47: 685 713, 1993

13) Willey, J.; J. SCHWEDOCK \& R. LOSICK: Multiple extracellular signals govern the production of a morphogenetic protein involved in aerial mycelium formation by Streptomyces coelicolor. Genes \& Development 7: 895 903, 1993

14) David, L. \& A. Kergomard: Production by controlled biosynthesis of a novel ionophore antibiotic cezomycin (demethylamino A 23187). J. Antibiotics 35: 1409 1411, 1982 